\title{
Meiofaunal distribution in Hornsund fjord, Spitsbergen
}

\author{
Katarzyna Grzelak $\cdot$ Lech Kotwicki
}

Received: 15 April 2011 / Revised: 1 July 2011 / Accepted: 7 July 2011 / Published online: 29 July 2011

(C) The Author(s) 2011. This article is published with open access at Springerlink.com

\begin{abstract}
The meiofaunal community structure at 32 stations in Hornsund fjord $\left(77^{\circ} \mathrm{N}\right)$ was investigated, and results were compared with data from another Spitsbergen fjord, Kongsfjorden $\left(79^{\circ} \mathrm{N}\right)$. Steep environmental gradients of sedimentation, organic matter content, and salinity from the inner to the outer basin of the fjord are present due to intensive glacial discharges of meltwater and ice. As the natural environmental disturbances were described for macrofauna benthic communities before, we aimed to check whether the same pattern occurs among meiofauna. A total of 12 higher meiofaunal taxa were recorded, with nematodes predominating at all stations. Non-parametric multivariate analyses demonstrated clear differences in meiofaunal abundance and composition between stations in the glacial bay and in the outer part of the fjord. Meiofaunal abundance increased with increasing distance from the source of disturbance, which in our study is tidal glaciers. Therefore, the current study demonstrates that the spatial structure of meiofauna is affected by the natural environmental disturbance, and analysis of meiofaunal assemblages can be used to assess the effect of such disturbances.
\end{abstract}

Keywords Svalbard $\cdot$ Arctic $\cdot$ Meiofauna

Environmental disturbance

\section{Introduction}

The ecological importance of meiofauna is well established, and this component of the benthic community has

K. Grzelak $(\bowtie) \cdot$ L. Kotwicki

Institute of Oceanology, Polish Academy of Sciences,

ul. Powstancow Warszawy 55, 81-712 Sopot, Poland

e-mail: kgrzelak@iopan.gda.pl been studied in detail in many parts of the world. However, in contrast to tropical and temperate latitudes, studies of meiofaunal communities in Arctic regions have received less attention. Meiofauna are an important and extremely diverse component of benthic heterotrophic assemblages. They participate in energy transfer through the ecosystem and are an important link between primary producers and higher trophic levels in benthic systems (Giere 2009). In some cases, they may even exceed the macrofauna in biomass and make a significantly greater contribution to the processing of carbon by benthic communities than the larger macrofauna (McLachlan and Brown 2006). Due to their short life cycles (in most cases very much less than 1 year), high turnover rates, and the lack of planktonic stages, meiofauna are particularly sensitive to changes in environmental parameters and thus are useful in assessing environmental disturbances (Kennedy and Jacoby 1999). Abundance and community composition of meiofauna are reflections of processes such as pelagic-benthic coupling, mineral sedimentation, and freshwater glacier input; the latter is one of the major natural environmental disturbances in polar habitats (e.g. Grebmeier and Barry 1991; Kotwicki et al. 2004; Wlodarska-Kowalczuk et al. 2005). Physical disturbances on both spatial and temporal scales are highly variable, and benthic communities have to struggle with theirs structuring force.

Benthic diversity and biomass can significantly change from outer to inner parts of Arctic fjords, as has been documented in studies of macrofaunal communities (Kendall and Aschan 1993; Holte et al. 1996; Wlodarska-Kowalczuk et al. 2005). In this study, we examined the meiofaunal community along an environmental gradient in the Hornsund, which is an open glacial fjord located on the south-west coast of Spitsbergen. In this fjord, environmental gradients are present in the form of sediment disturbance, organic 
content changes, and intensified sediment deposition at the frontal zone of glaciers. Hornsund fjord has been selected as one of the 'All Taxon Biodiversity Inventory' (ATBI) sites as being representative of typical Arctic marine ecosystems. Moreover, due to its location in the zone of increasing air temperature and enlarged extent of Atlanticderived waters (the major heat distributors) on the West Spitsbergen Shelf (Serreze et al. 2000; Walczowski and Piechura 2006; Walczowski and Piechura 2007), Hornsund together with Kongsfjorden (located on the north-west coast of Spitsbergen and characterized as a warm fjord) was selected as sites for monitoring the effects of climate change (Warwick et al. 2003).

This study was conducted within the framework of an extensive survey focused on the Hornsund benthic ecosystem, which took place in the last decade, and it was designed to be comparative with a study conducted in Kongsfjorden (Kotwicki et al. 2004). Prior benthic investigations into Hornsund were focused mostly on the macrozoobenthos and neglected meiofaunal communities. Legezynska et al. (2000) studied benthic scavengers (necrophagic fauna) collected by baited traps, Ronowicz (2005) investigated macrofaunal distribution on gravel beaches, Ronowicz et al. (2008) described hydroid communities, Kedra and Wlodarska-Kowalczuk (2008) concentrated on distribution and diversity of sipunculan fauna, and Wlodarska-Kowalczuk et al. (2009) described macrofaunal assemblages associated with macroalgae in an Arctic kelp forest. Urban-Malinga et al. (2009) published the only report concerning intertidal meiofaunal communities on selected beaches of Hornsund fjord. Thus, results reported in the present study represent the first data on subtidal meiofaunal communities of Hornsund fjord.

This study addressed the following questions: Do meiofaunal densities change along the Hornsund fjord's axis? Are these changes connected with hydrology and topography of the fjord? What kinds of environmental factors affect meiofaunal community structure throughout the fjord? Are meiofaunal densities in Hornsund fjord different from those in Kongsfjorden, and what causes the similarities/differences between the two fjords?

\section{Materials and methods}

\section{Study area}

Hornsund fjord is the southernmost, open, glacial fjord located on the west coast of Spitsbergen (Fig. 1). It is $30 \mathrm{~km}$ long and up to $15 \mathrm{~km}$ wide and has an average depth of $90 \mathrm{~m}$. Its outer part is connected with the Greenland Sea, whereas the shallower inner basin, which is called Brepollen, is partially isolated from the remaining part of the fjord
Table 1 Basic data on sampling sites

\begin{tabular}{lllll}
\hline Station & $\begin{array}{l}\text { Latitude } \\
{\left[{ }^{\circ} \mathrm{N}\right]}\end{array}$ & $\begin{array}{l}\text { Longitude } \\
{\left[{ }^{\circ} \mathrm{E}\right]}\end{array}$ & $\begin{array}{l}\text { Depth } \\
(\mathrm{m})\end{array}$ & $\begin{array}{l}\text { Grain size } \\
<0.063 \mathrm{~mm}(\%)\end{array}$ \\
\hline A1 & 76.98 & 15.42 & 104 & 90.40 \\
$\mathrm{~A} 2$ & 76.97 & 15.43 & 140 & 71.78 \\
$\mathrm{~A} 3$ & 76.95 & 15.45 & 137 & 95.26 \\
$\mathrm{~A} 4$ & 76.93 & 15.46 & 141 & 95.42 \\
A5 & 76.92 & 15.48 & 138 & 86.34 \\
$\mathrm{~B} 1$ & 76.99 & 15.66 & 56 & 50.84 \\
B2 & 76.98 & 15.67 & 150 & 92.44 \\
B3 & 76.97 & 15.68 & 115 & 88.03 \\
B4 & 76.95 & 15.70 & 120 & 74.50 \\
B5 & 76.94 & 15.71 & 96 & 80.78 \\
C1 & 77.00 & 15.87 & 173 & nd \\
C2 & 76.89 & 15.87 & 190 & 92.57 \\
C3 & 76.97 & 15.87 & 215 & 95.07 \\
C4 & 76.95 & 15.86 & 25 & 9.38 \\
D1 & 77.03 & 15.90 & 106 & 95.56 \\
D2 & 77.01 & 16.01 & 103 & 95.56 \\
D3 & 77.00 & 16.00 & 103 & nd \\
D4 & 76.98 & 16.03 & 109 & 93.22 \\
E1 & 77.02 & 16.13 & 90 & 92.45 \\
E2 & 77.00 & 16.17 & 46 & 87.44 \\
E3 & 76.98 & 16.19 & 112 & 93.98 \\
E4 & 76.97 & 16.23 & 115 & 97.21 \\
E5 & 76.95 & 16.25 & 118 & 99.06 \\
E6 & 76.93 & 16.27 & 110 & 97.25 \\
F1 & 77.01 & 16.29 & 80 & 97.31 \\
F2 & 77.00 & 16.32 & 87 & 90.97 \\
F3 & nd & nd & 122 & 85.80 \\
F4 & 76.98 & 16.38 & 61 & 95.36 \\
G1 & 77.03 & 16.44 & 41 & 98.06 \\
G2 & 77.02 & 16.46 & 114 & 98.78 \\
G3 & 77.01 & 16.49 & 140 & 97.43 \\
G4 & 77.00 & 16.52 & 78 & 92.59 \\
\hline$d n$ & 76.98 & 16.55 & 45 & 97.11 \\
\hline
\end{tabular}

nd no data

by the Treskelen Peninsula. The hydrology of Hornsund is shaped by the complex dynamics of different water masses. The interplay between the warm Atlantic-derived waters, cold Arctic water masses transported by the East Spitsbergen Current, and the fjord's own inner Local Brackish Waters causes Hornsund to be colder than the northern fjords located on the west cost of Spitsbergen (Swerpel 1985; Weslawski et al. 1991; Saloranta and Haugan 2004). Thirteen tidewater glaciers are present in Hornsund, and five of the most active ones are located in the inner basin (Fig. 1). The hydrological conditions of Brepollen differ from those of the outer part of Hornsund. Topographical isolation of the glacial bay, the presence of five glaciers, 
and the input of fresh water from glacier channels and rivers cause visible water column stratification in Brepollen during the summer. The strong impact of glacier meltwater can result in high amounts of inorganic suspension (Hop et al. 2002; Svendsen et al. 2002), which limits primary production in the inner basin (Keck et al. 1999) and causes mass zooplankton mortalities (Weslawski and Legezynska 1998). Large amounts of mineral particles reduce the thickness of the euphotic zone (Urbanski et al. 1980) and affect organisms living in the sediment (Wlodarska-Kowalczuk and Pearson 2004). The fjord floor is covered mostly with mud containing less total inorganic carbon (TIC-mainly from carbonate rocks) in the sediments of Brepollen (inner fjord) than in the outer fjord sediments, $0.31 \pm 0.15 \%$ vs. $0.99 \pm 0.22 \%$, respectively (Schettler and Szczucinski 2005, unpublished data). However, distribution of total organic carbon (TOC) in surface sediments reveals opposite relationship. TOC higher values (1.75-1.99\%) are in the inner basin and lower (0.80-1.82\%) in the outer part of the fjord (Schettler and Szczucinski 2005, unpublished data; Szczucinski et al. 2006).

The total outflow of Hornsund melting glaciers was estimated to $0.79 \mathrm{~km}^{3}$ per year (Beszczynska-Moller et al. 1997). Currently, the volume of freshwater run-off might be even higher due to rising temperatures and the continuous retreat of glaciers (Jania 1988; Palli et al. 2003).
Sampling and laboratory analyses

Samples were collected in July 2005 from the R/V Oceania (Polish Academy of Sciences) from a series of 32 stations located at profiles $\mathrm{A}-\mathrm{G}$, which ranged from the open sea to the innermost part of Hornsund fjord (Table 1; Fig. 1). All samples were taken using a box corer. For the analysis of meiofauna, one sample from each box core was collected. A plexiglass tube with an inner diameter of $3.6 \mathrm{~cm}$ was pushed into the sediment to a depth of $5 \mathrm{~cm}$. After retrieval of the core sample, all material was fixed with $4 \%$ formaldehyde-seawater solution. The LUDOX HS silica density gradient centrifugation technique (density $1.18 \mathrm{~g} / \mathrm{cm}^{3}$ ) was used to extract animals from the sediment (Burgess 2001). After centrifugation, the supernatant was sieved through a $500-\mu \mathrm{m}$ and a $38-\mu \mathrm{m}$ sieve. Samples retained on the $38-\mu \mathrm{m}$ sieve were stained with Rose Bengal. Subsequently, metazoan meiofauna were classified to higher taxa level (phylum, class or order) under a stereo microscope. Meiofaunal abundance was calculated per $10 \mathrm{~cm}^{2}$.

To determine the grain-size distribution of the sediment, samples were taken from the upper $5 \mathrm{~cm}$ of the box core in the vicinity of the meiofaunal core samples, dried and sieved through thirteen half phi intervals. The sediment retained on each sieve was weighed, and particle size

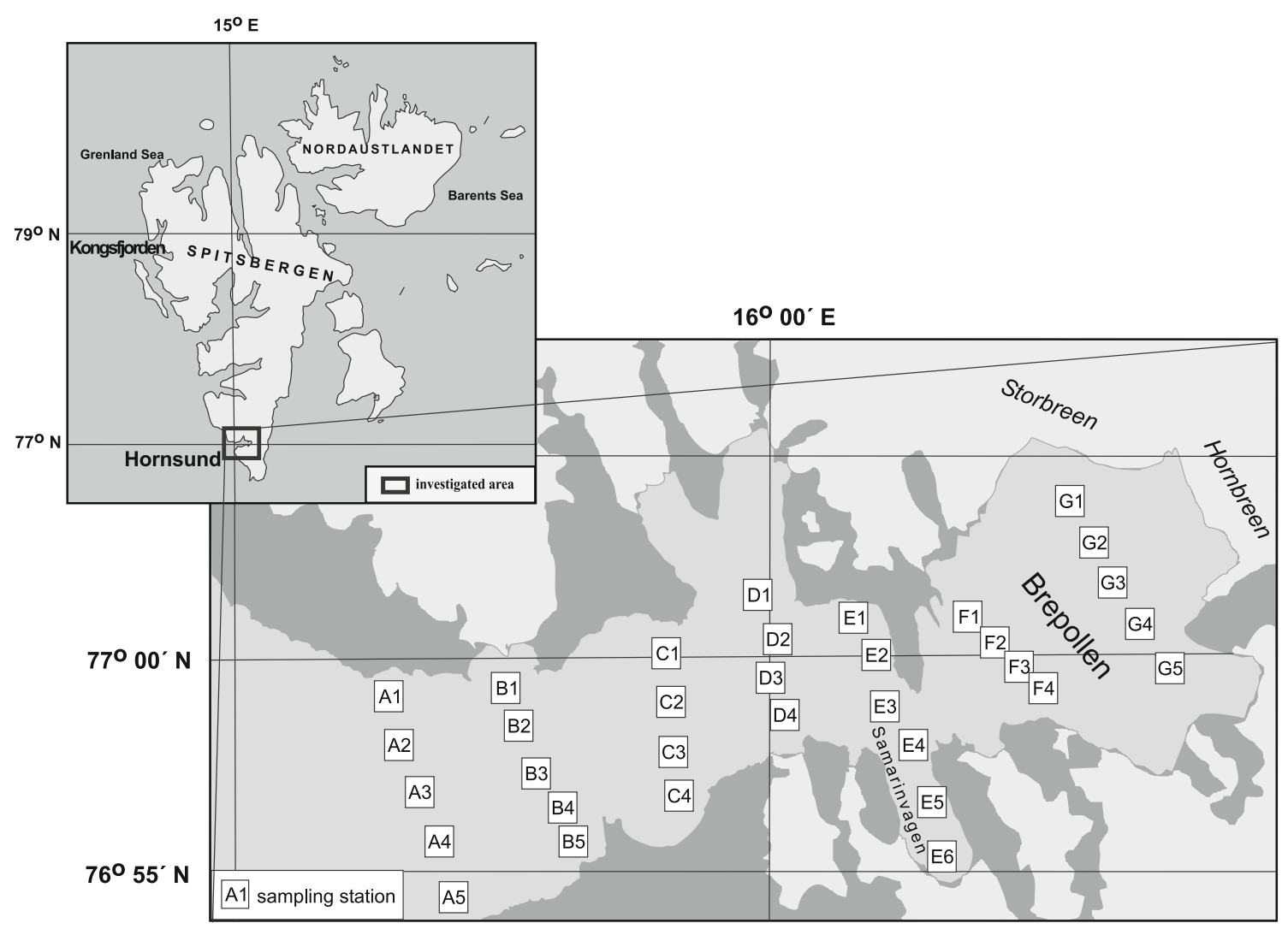

Fig. 1 Map of Svalbard Archipelago with location of Hornsund fjord and sampling stations 
distribution was defined according to the Wentworth classification (Wentworth 1922).

\section{Statistical analyses}

Multivariate analyses available in the PRIMER package (Clarke and Gorley 2006) were performed on the meiofaunal abundance and sediment data. The meiofaunal data were double root transformed, which reduced the influence of the most numerous taxa and gave a more balanced view of the community structure. Before analysis, the environmental data were log transformed and normalized. Oneway ANOSIM was used to test for differences in meiobenthic composition and sediment characteristics (grain size, total and organic carbon content) between two a priori set groups of samples representing the different basins in the fjord (profiles A-E vs. profiles F-G). The ANOSIM procedure was applied to Bray-Curtis similarities (for faunal samples) and Euclidean distance (for environmental samples). Additionally, for meiofaunal data, ordination of samples by non-metric multidimensional scaling was performed. The non-parametric Mann-Whitney $U$-test was used to test for differences in meiofaunal densities between inner and outer Hornsund basins, for general differences in meiofaunal densities between Hornsund and Kongsfjorden and for differences between basins (inner/outer). Meiofaunal density data for Kongsfjorden were from Kotwicki et al. (2004). The analyses were performed using the software package Statistica (Statistica, version 6). A formal significance test for meiofaunal differences between groups of samples collected in basins of different fjords was performed using the ANOSIM test.

To interpret and summarize the major patterns of variation within the meiofauna data from the two fjords, we used principal component analysis (PCA) in the CANOCO for Windows v4.5 package (ter Braak and Smilauer 2002). The results of a preliminary detrended correspondence analysis based on the length of the main gradient indicated that PCA was the most appropriate method to use in our case (ter Braak and Smilauer 2002). In the resulting biplot, the length of the arrow indicates the importance of the variable (e.g. variables with short arrows do not vary much across the diagram), and the coordinates of the arrow head are correlated with the axes (e.g. the smaller the angle between the arrow head and the axis, the higher the correlation). The axes are uncorrelated.

\section{Results}

Fjordic subtidal sediments were composed of very finegrained deposits. Throughout the Hornsund fjord, the sediments were rather homogeneous, and almost all stations were dominated by mud; the exceptions were stations $\mathrm{C} 4$ and B1, where the content of sand was relatively high $(9.38$ and $50.84 \%$, respectively). The stations characterized by the finest sediments were located in the inner part of the fjord in Samarinvagen and Brepollen bay (Table 1). The ANOSIM test indicated that groups of samples representing different fjord basins differed significantly in terms of sediment characteristics $(\mathrm{R}=0.588, P=0.001)$.

A total of 12 higher meiofaunal taxa and 2 larval stages were recorded in Hornsund fjord in this study. Between five and eleven taxa were found at each station (Table 2). Only Nematoda occurred at all stations. However, Harpacticoida, Polychaeta, and Kinorhyncha were also common; they were present in over $80 \%$ of the analysed samples. Except for nematodes, the presence of the other taxa depended on the station's location. The outer basin was characterized by $100 \%$ occurrence of Harpacticoida, Polychaeta, and Copepoda nauplii, together with a high occurrence of Kinorhyncha and Ostracoda (over 80\%). In the glacial bay, frequency of occurrence of all common taxa decreased. Most of the other taxa appeared only occasionally (e.g. Acari and Oligochaeta) or in very low numbers per station (e.g. Bivalvia and Cnidaria).

Meiofaunal abundances varied greatly between the fjord stations (Table 2; Fig. 2). The lowest total density was recorded at station $\mathrm{G} 3\left(176 \mathrm{ind} / 10 \mathrm{~cm}^{2}\right)$, whereas the highest was found at station C2 $\left(3,199 \mathrm{ind} / 10 \mathrm{~cm}^{2}\right)$. A threefold lower value in mean abundance was observed in the inner basin $\left(505 \mathrm{ind} / 10 \mathrm{~cm}^{2}\right)$ than in the outer basin $(1,416 \mathrm{ind} /$ $\left.10 \mathrm{~cm}^{2}\right)$.

All stations in the fjord were dominated by nematodes, which together with the second most abundant taxon constituted up to $90 \%$ (or even more) of the total meiofaunal density. In the outer basin, harpacticoids followed nematodes in abundance, whereas in the inner part, polychaetes were the second most abundant meiofaunal organism. The density of nematodes ranged from 136 to 2,976 ind/ $10 \mathrm{~cm}^{2}$. Compared with the outer basin, considerably, lower nematode abundances were observed in the glacial bay (Fig. 3). Harpacticoids were the second most important group in terms of meiofaunal abundance in the outer part of Hornsund. The highest densities (up to $164 \mathrm{ind} /$ $10 \mathrm{~cm}^{2}$ ) were observed at the stations of profile $\mathrm{C}$, which was situated in the central part of the outer basin (Fig. 3). Mean abundance of Harpacticoida in the outer basin was $86 \mathrm{ind} / 10 \mathrm{~cm}^{2}$. In the inner part of Hornsund, harpacticoid abundance was much lower, with a mean density of $14 \mathrm{ind} / 10 \mathrm{~cm}^{2}$. Kinorhyncha showed a similar distribution pattern (Fig. 3): the lowest densities were observed in the inner part of the fjord (mean abundance: 2 ind $/ 10 \mathrm{~cm}^{2}$ ), whereas stations located in the outer part were characterized by higher densities (maximum value of $82 \mathrm{ind} / 10 \mathrm{~cm}^{2}$ at station C2). Polychaetes were the second most abundant 


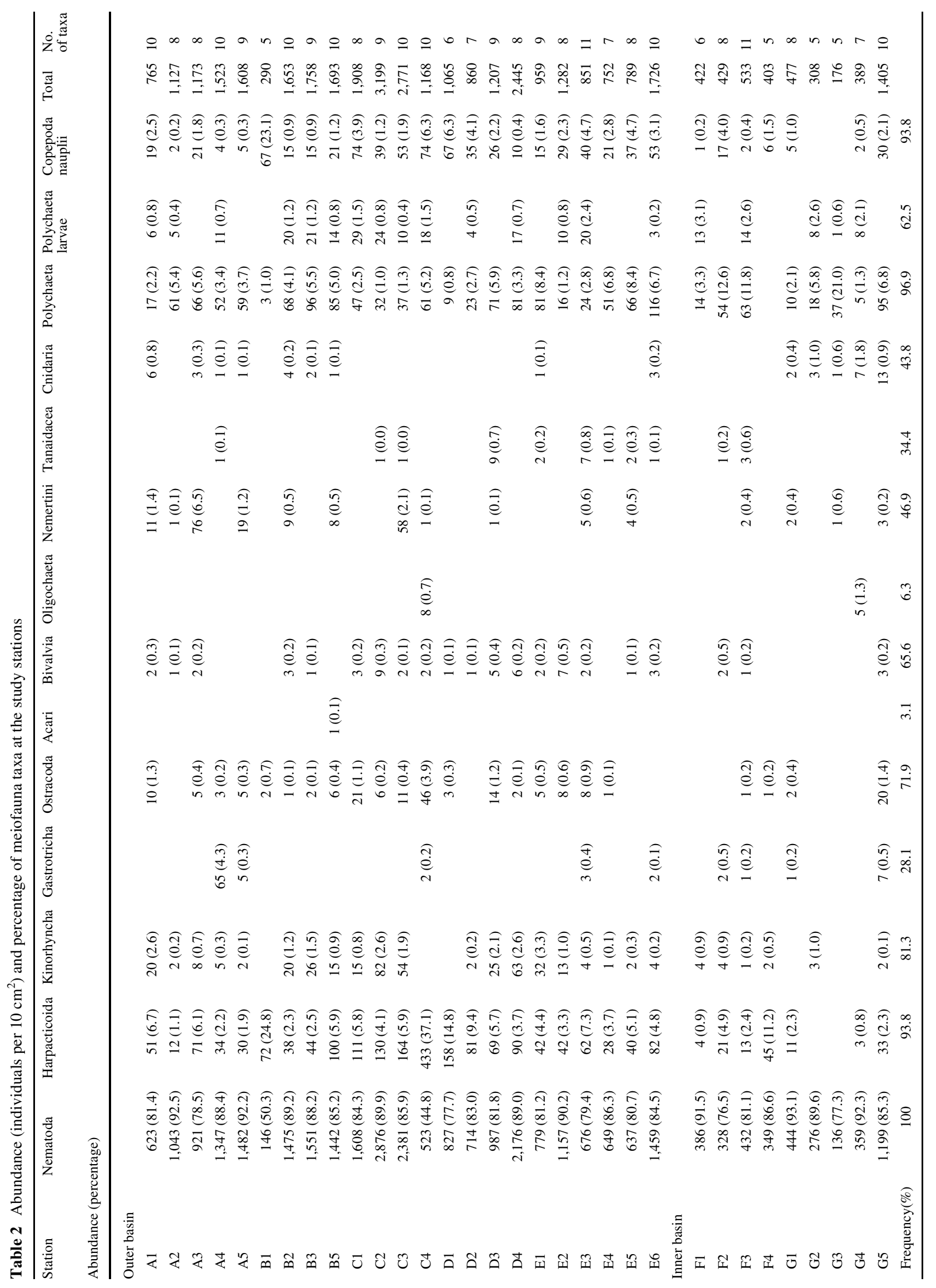




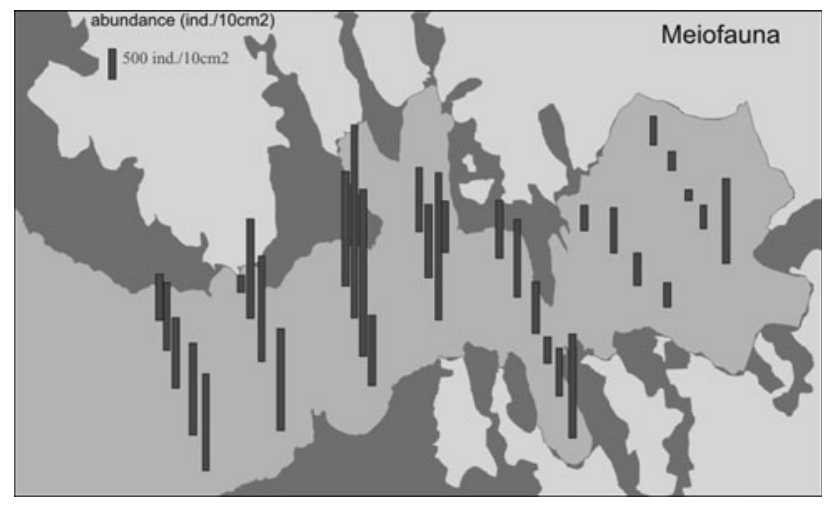

Fig. 2 Total meiofaunal abundance (ind $/ 10 \mathrm{~cm}^{2}$ ) along Hornsund fjord

organism in the inner basin, where their densities reached $95 \mathrm{ind} / 10 \mathrm{~cm}^{2}$ (station G5). In the outer basin, the maximum density of polychaetes was $119 \mathrm{ind} / 10 \mathrm{~cm}^{2}$ at station E6 (Table 2; Fig. 3).

Total meiofaunal densities differed significantly between the inner and the outer Hornsund basins (Mann-Whitney $U$ test, $P<0.001)$. The relatively high value of the $\mathrm{R}$ statistic (ANOSIM test: $\mathrm{R}=0.616, P=0.001$ ) indicated that samples collected from different basins were easily separable with regard to meiofaunal composition, as can be seen in the ordination plot. Two meiofaunal communities can be distinguished: Outer profiles A-E formed one assemblage, and inner profiles F-G formed the other (Fig. 4). However, near-shore station G5 was classified into the first group due to high nematode density.

\section{Discussion}

Meiofaunal assemblages in Hornsund

The meiofaunal assemblages from the outer areas of the Hornsund fjord differed significantly from those sampled from the inner bay. A clear discontinuity in the meiofauna community along the fjord axis was observed, and division into a glacial (inner) basin community and an outer basin community was unequivocal. Low meiofaunal densities characterized the glacial bay community, and almost all taxa analysed were less prevalent in this area compared with their relative abundance in the outer basin community. The highest meiofaunal densities were observed in the central part of the fjord. The meiofaunal distribution pattern observed in this study showed tendencies similar to those
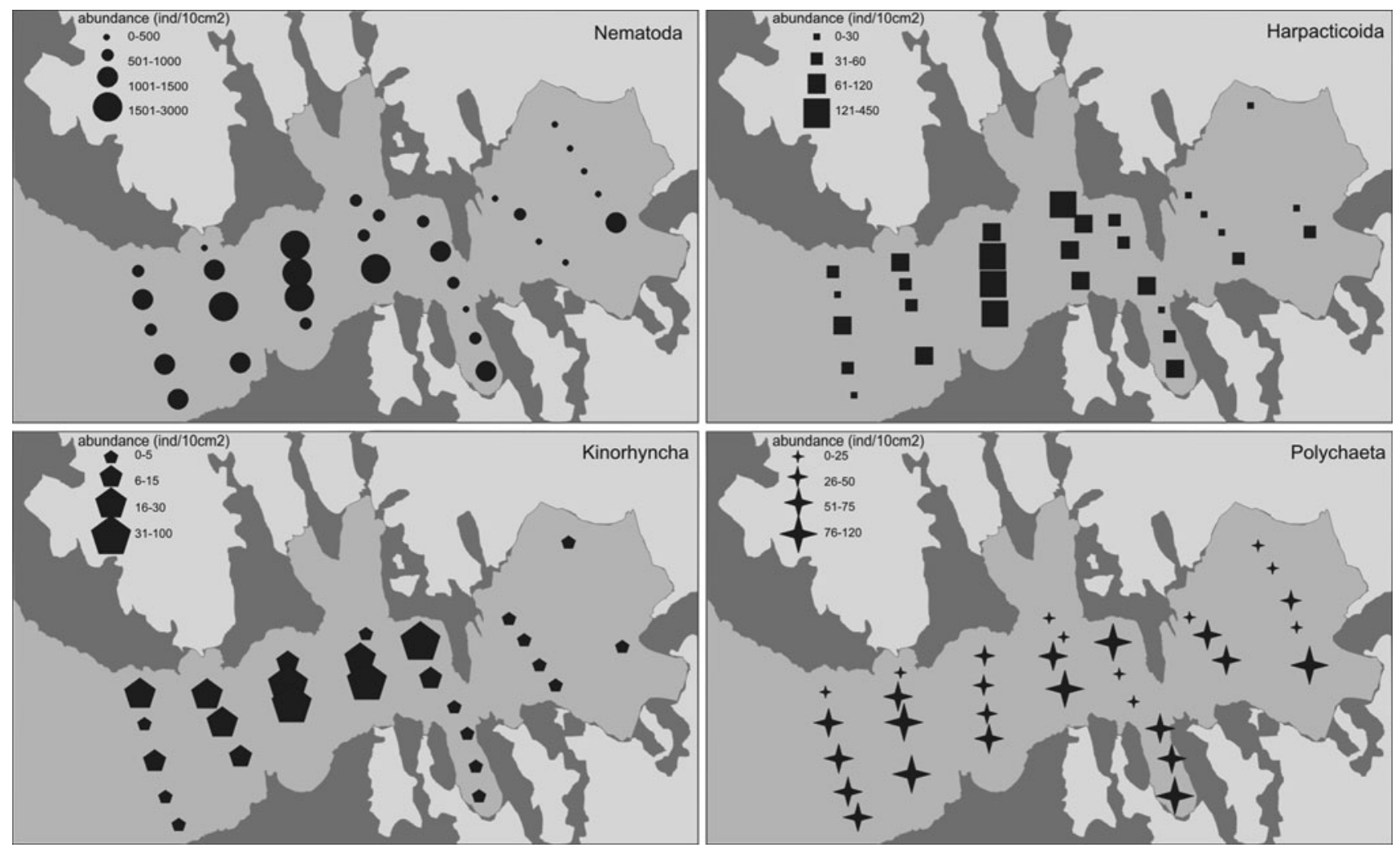

Fig. 3 Abundance (ind $/ 10 \mathrm{~cm}^{2}$ ) of four major meiofaunal taxa (Nematoda, Harpacticoida, Kinorhyncha, and Polychaeta) in Hornsund. Size of symbols related to abundances of taxa at sampling stations 


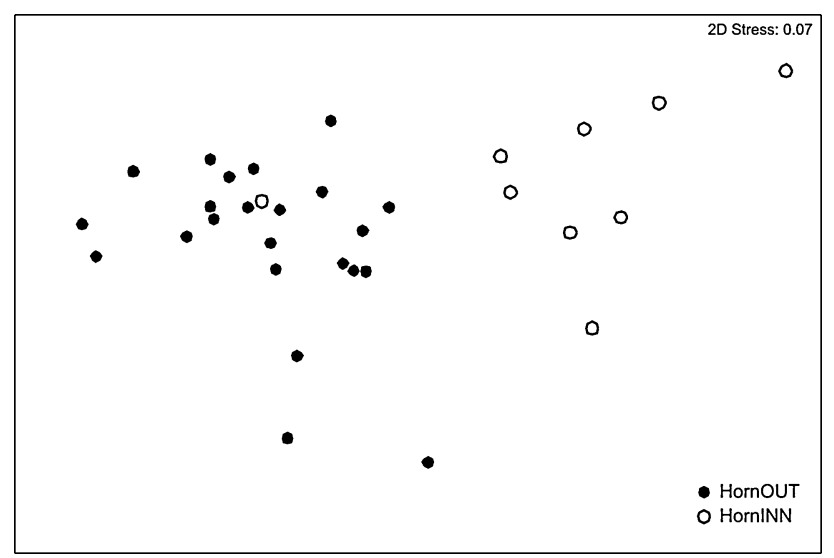

Fig. 4 Non-metric MDS plot of Bray-Curtis similarities of doubled root transformed meiofaunal data

observed for macrozoobenthos in Svalbard fjords (Görlich et al. 1987; Holte et al. 1996; Wlodarska-Kowalczuk and Pearson 2004). The forefields of the glaciers (inner fjord) always have low faunal abundance and biomass, independent of water depth. Depth-related changes in these parameters are less pronounced than are changes related to location within the fjord. The main factors responsible for such pattern seem to be sediment processes (e.g. sedimentation and sediment stability) (Görlich et al. 1987).

In our study, the negative influence of tidal glaciers was reflected by the low density of nematodes and the lack of harpacticoids at stations in the vicinity of Storbreen and Hornbreen glaciers. Meiobenthic harpacticoids can be affected greatly by natural disturbances, mostly because their occurrence is restricted to the upper sediment layers; they favour epibenthic life and larger grain size sediments, which makes them sensitive to reduced oxygen supply (Coull 1970; Giere 2009). Thus, ongoing sedimentation in the frontal zone of glaciers generates unfavourable conditions for harpacticoids (e.g. interstitial space becomes too small and clogged with silt). This may explain the much lower densities of harpacticoids in Brepollen bay compared to the outer basin. In contrast to harpacticoids, nematodes are clearly resistant to a number of physical disturbances; however, the response of the nematode community depends on the intensity, frequency, and type of disturbance (Schratzberger and Warwick 1998 and references therein). A number of species can withstand suboxic, anoxic, or even sulphidic conditions, and some can migrate deep into the sediment or into the water column to survive unfavourable environmental conditions (Wetzel et al. 2002; Steyaert et al. 2007; Giere 2009). Meiobenthic polychaetes seem to be quite resilient to physical disturbance, as their abundance was relatively high in the inner basin. Fine sediments are used in tube building, and meiobenthic polychaetes have a number of adaptations for meiofaunal and interstitial life (e.g. no planktonic trochophora larva). In contrast to previous reports (Lee et al. 2001a; Kotwicki et al. 2004), in our study, the disturbance effect of glaciers was not reflected in the number of meiofaunal taxa found at the inner bay stations. The glacial bay contained stations with both the lowest and the highest number of taxa. The scale of the impact on and response of benthic organisms to disturbance by glaciers depend on the glacier activity, which directly influences a wide spectrum of processes, such as organic matter availability, concentration, and sedimentation rate of mineral suspensions, salinity variability, and iceberg scouring (Görlich et al. 1987; Kendall 1994; Lee et al. 2001a). Meiofaunal response to these kinds of natural stresses has not been sufficiently studied yet.

The concentration of suspended mineral solids in the glacier outflows reaches up to $250 \mathrm{mg} / \mathrm{l}$ in the frontal zone of Hornsbreen and Storbreen (unpub. data, IOPAS), and the meltwater currents transport suspended solids several kilometres away from the glaciers. Because sediment flux through the water column increases in the lower part of water column and also reaches the bottom, sedimented material directly influences bottom dwellers. The meiofaunal community in Brepollen bay is not the only component of the benthos that is affected by glaciers. In studies conducted in 2002, macrofaunal organisms showed significantly lower abundances at profiles $\mathrm{F}$ and $\mathrm{G}$ (inner basin), together with much lower diversity, in comparison with those at outer profiles (mean abundance: 370 ind $/ 0.1 \mathrm{~m}^{2}$ vs. $967 \mathrm{ind} / 0.1 \mathrm{~m}^{2}$ ) (Maciejewska 2007). Glacial assemblages were dominated by mobile surface detritus feeders and predators, which are adapted to withstand high degrees of disturbance. Sessile fauna characterized the outer basin, where environmental conditions are more stable.

\section{Comparison of meiofauna between Hornsund} and Kongsfjorden

Compared with Kongsfjord, Hornsund is regarded as the fjord with a more Arctic character (Weslawski et al. 2006; Walkusz 2006). Observed differences in the physical environment influenced meiofaunal assemblages in both fjords. The most significant distinction between the fjords concerned meiofaunal density. Compared with Hornsund, in Kongsfjorden, meiofaunal abundance was significantly lower throughout the axis of the fjord (Mann-Whitney $U$ test, $P<0.001$, Fig. 5a). Like in Hornsund, two meiofaunal communities were distinguishable (a glacial bay assemblage and an outer basin assemblage) (for details, see Kotwicki et al. 2004); however, respective basins are incomparable with each other according to total meiofaunal density (Fig. 5b). PCA and the ANOSIM test confirmed significant differences in meiofaunal community between fjords (Table 3; Fig. 6 respectively). The eigenvalues for PCA axes 1 and 2 were 0.73 and 0.12 , respectively, thus 

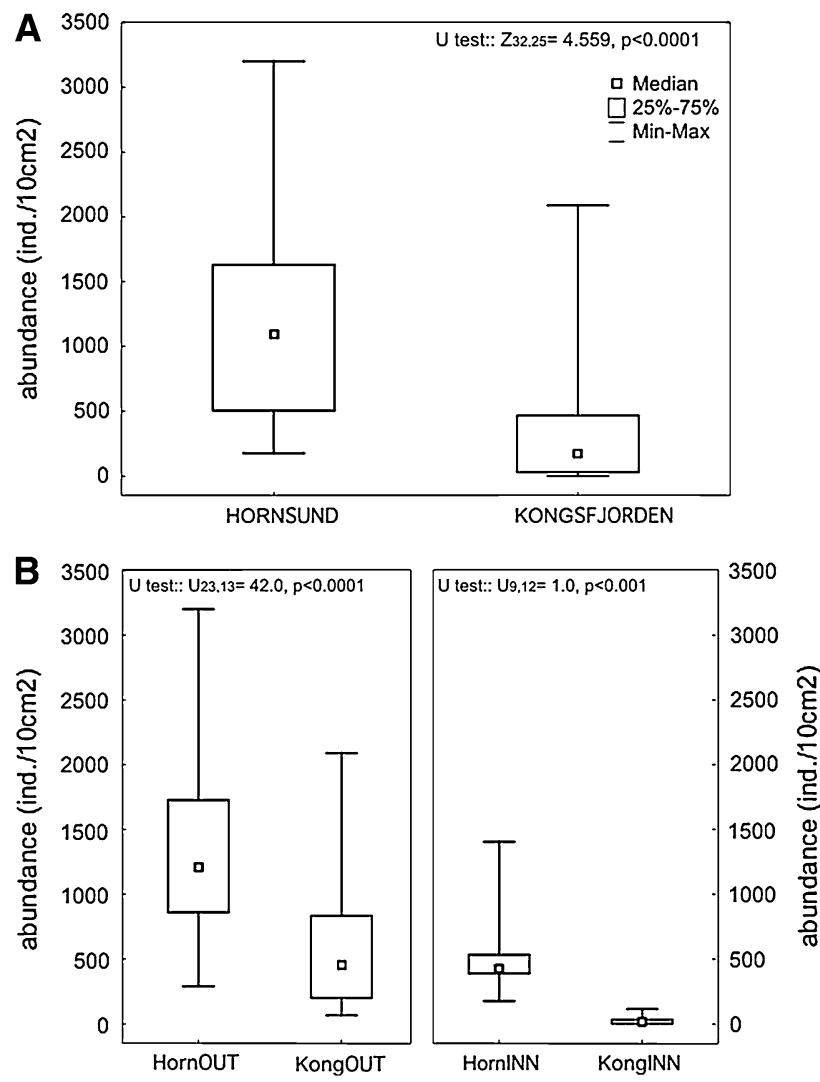

Fig. 5 Box plot (with median and 25 quartiles) showing total meiofaunal abundance (ind $/ 10 \mathrm{~cm}^{2}$ ), including results of Mann-Whitney $U$ test testing differences in meiofaunal densities between a-all sampling stations at Hornsund fjord and Kongsfjorden; b-sampling stations in the outer (OUT) and inner (INN) basins at Hornsund fjord (Horn) and Kongsfjorden (Kong)

capturing $85 \%$ of the total variance in the data. A clear division of four groups was present, each characterizing a particular fjord and basin (Fig. 6). Nematodes greatly influenced observed groupings and were responsible for the largest part of the variance. Moreover, turbellarians strongly influenced the outer assemblage of Kongsfjorden, whereas polychaetes were more important in Hornsund assemblages.

The observed differences in meiofaunal densities between the fjords raise the following question: What is the reason for this dissimilarity? Many studies have indicated that meiofaunal densities are determined largely by the quantities and qualities of food available (e.g. organic content, bacterial density, and diatoms) in both the sediments and the water column (McLachlan 1977; Montagna et al. 1983; Lee et al. 2001b; Moreno et al. 2006). Although the levels of particulate organic matter are not a direct measure of food availability, they may be used as an indicator for this parameter. Concentration of TOC in Hornsund sediments was higher than that in Kongsfjorden (mean concentration: $1.58 \%$ vs. $0.85 \%$, respectively; Schettler and
Table 3 Results of ANOSIM test comparing within group and between group similarities of meiofauna samples collected in the outer (OUT) and inner (INN) basins at Hornsund fjord (Horn) and Kongsfjorden (Kong)

\begin{tabular}{lll}
\hline & \multicolumn{2}{l}{ Meiofauna } \\
\cline { 2 - 3 } & $\mathrm{R}$ & $P$ \\
\hline Global test & 0.626 & 0.001 \\
Pairwise contrasts & & \\
HornINN-HornOUT & 0.616 & 0.001 \\
KongINN-KongOUT & 0.736 & 0.001 \\
HornINN-KongINN & 0.622 & 0.001 \\
HornOUT-KongOUT & 0.556 & 0.001 \\
\hline
\end{tabular}

Szczucinski 2005 unp. data and Wlodarska-Kowalczuk and Pearson 2004). In particular, the glacial bay of Kongsfjorden, where meiofaunal abundance was remarkably low (range: $1-114 \mathrm{ind} / 10 \mathrm{~cm}^{2}$ ), was characterized by very low organic carbon values (up to $0.5 \%$ ). This coincided with intensive outflow coming from Kongsbreen glacier, where concentrations of suspended mineral solids reached $400 \mathrm{mg} / \mathrm{l}$ (Zajaczkowski 2008). Kongsbreen is described as the most active Spitsbergen glacier (Lefauconnier et al. 1994). The highest deposition of mineral sediments occurs in the summer, when samples were collected. Because concentration of suspended mineral solids in the frontal zone of Kongsbreen is almost twice as high as that of Hornsbreen and Storbreen, it is highly likely that intense and accumulating deposition of fine sediments containing very little organic matter reduced the meiofaunal population in the inner bay of Kongsfjorden.

The coupling between pelagic and benthic compartments of the marine ecosystem is clearly important for the functioning of both systems. It is commonly accepted that the downward flux of material controls both the biomass and the production of the benthos (e.g. Graf 1989; Ambrose and Renaud 1995; Danovaro et al. 1999). The amount of surface-produced organic carbon reaching the benthos depends first on the intensity of primary production and second on the level of heterotrophic grazing of material as it descends through the water column. As revealed by Piwosz et al. (2009), primary production rates are an order of magnitude higher in Hornsund than in Kongsfjorden. Even if some of these observed differences might have been due to different blooming stages, more productive character of Hornsund should be underline. Differences in phytoplankton assemblages in both fjords and basins have been previously studied (Eilertsen et al. 1989; Wiktor and Wojciechowska 2005) and attributed to differences in water mass characteristics. Different species composition and phytoplankton biomass directly influence primary production. In the comparably warmer waters of Kongsfjorden, 
Fig. 6 Ordination diagram based on principal component analysis of log-transformed meiofaunal data at the sampling stations in Hornsund fjord and Kongsfjorden

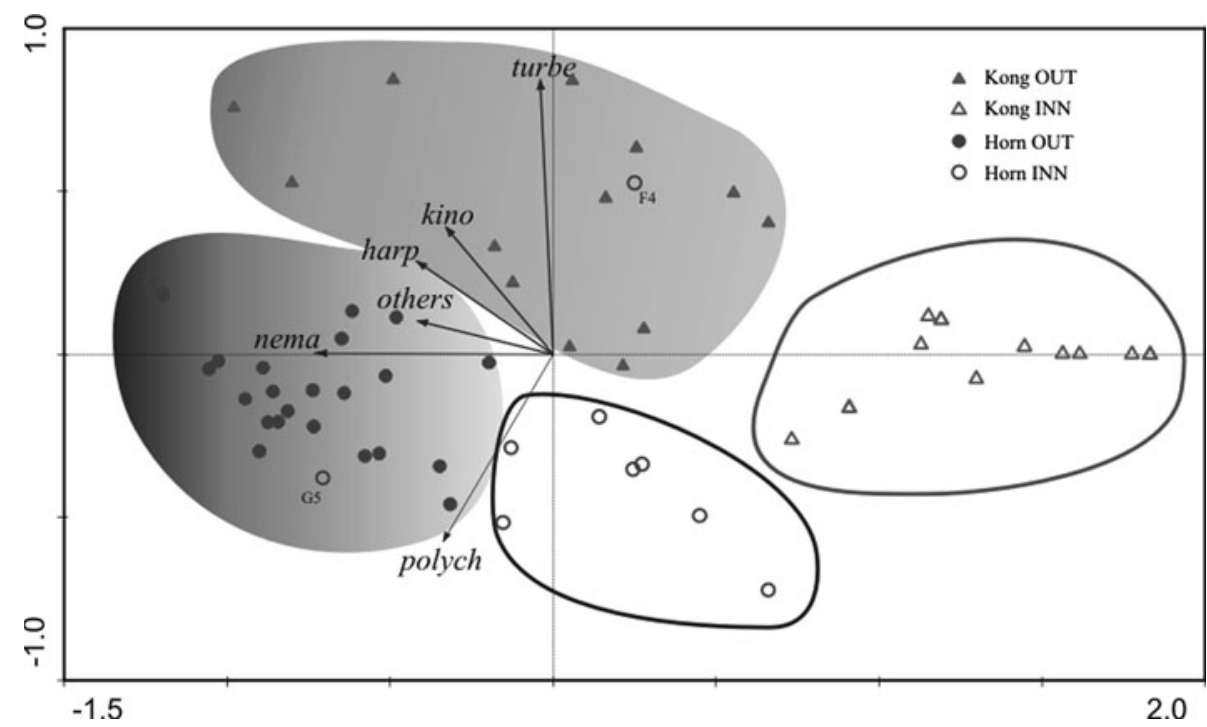

oceanic species that are typical of Atlantic-derived water masses are found (Okolodkov et al. 2000; Hop et al. 2002; Piwosz et al. 2009). Moreover, a relatively high proportion of crypthophytes and nanoflagellates in the total phytoplankton biomass were observed in Kongsfjorden (Piwosz et al. 2009). Individuals from these groups are small, which results in a relatively lower biomass. Additionally, autotrophic flagellates (crypthophytes and dinoflagellates) have relatively low primary production rates (Throndsen 1970). In Hornsund, diatoms contributed more to biomass, and the productive layer in Hornsund is thicker than that in Kongsfjorden (Piwosz et al. 2009). Because high concentrations of suspended matter in surface waters (which is true for Kongsfjorden) decrease the extension of the euphotic zone in the fjords (Zajaczkowski 2008), differences in primary production and phytoplankton biomass between two fjords are highly reliable. Moreover, the Arctic character of Hornsund might favour the presence of cryopelagic species, which were most likely transported from Arctic waters via the East Spitsbergen Current.

The higher amount of organic matter in Hornsund than in Kongsfjorden may coincide with bacterial activity, which decreases with decreasing temperatures (Weston and Joye 2005). Microbes are likely an important factor in controlling the availability and quality of organic carbon that reaches the benthos. Bacteria in the sediments directly impact nutrient and carbon cycles, as they complete the final decomposition step by breaking down organic carbon and making it available for other organisms (Fenchel and Jørgensen 1977; Falkowski et al. 2008; Robador et al. 2009). However, little information is available about the bacterial community in Spitsbergen fjords (Jankowska et al. 2005; Jiang et al. 2005; Zeng et al. 2009; Piquet et al. 2010); thus, the relationship between bacterial activity and organic matter in Hornsund requires further study.
Finally, the zooplankton community and depth of both fjords may have caused some of the observed differences in organic matter concentration and, indirectly, in meiofaunal assemblages. On the one hand, abundance of zooplankton in Hornsund is several times lower compared with that in Kongsfjorden (Piwosz et al. 2009; Głuchowska et al. in prep.). On the other hand, Kongsfjorden is deeper: depths in the outer basin reach $428 \mathrm{~m}$ (average: 200-300 m), whereas the inner basin has a mean depth of $50-60 \mathrm{~m}$. Maximum depth in Hornsund is $250 \mathrm{~m}$, with an average of $90 \mathrm{~m}$. Shorter sedimentation time and lower abundances of prospective phytoplankton consumers means that quality and quantity of organic carbon reaching the benthic ecosystem likely is higher in Hornsund than in Kongsfjorden.

Nevertheless, food availability is not the only limiting factor for meiofaunal taxa. Others factors that influence meiofaunal communities include predation, competition, feeding pressure of the macrobenthos, and hydrodynamics (Hulings and Gray 1976; Bell and Coull 1978). However, because macrofaunal abundances were highly comparable between glacial bays in the investigated fjords and because even higher abundances were noted in the outer basin of Hornsund than in Kongsfjorden (Wlodarska-Kowalczuk 2001; Maciejewska 2007), the influence of macrobenthic pressure can be neglected.

Unfortunately, we were not able to use the same sampling gears in both fjords. Samples collected using different samplers may lead to different results (Somerfield and Clarke 1997). However, meiofaunal communities (nematodes in particular) in cores collected by subsampling box core and van Veen grab (used in Kongsfjorden by Kotwicki et al.) do not differ statistically (Somerfield and Clarke 1997). Thus, we treated materials collected from the two fjords as comparable, at least to some extent. For logistic reasons and because of the high cost of high Arctic studies, 
sampling opportunities and number of replicates that can be obtained are often seriously limited. Therefore, scientists have to deal with available data. In our study, possible differences resulting from different sampling time and sampling gears should not invalidate the general findings.

\section{Conclusions}

In conclusion, comparable environmental parameters, such as the lack of sediment stability, permanent mineral sedimentation processes, and glacial input of freshwater, appear to be responsible for the similar spatial distribution and community structure of meiofaunal communities in the two Svalbard fjords, Hornsund and Kongsfjorden. However, these environmental factors did not explain the significant differences in meiofaunal abundances between the two fjords. The relatively high meiobenthic densities in Hornsund relative to Kongsfjorden result from the relatively high primary productivity of the water column, higher zooplankton abundance, and low temperature near the bottom.

Acknowledgments The authors would like to express deep thanks to Georg Schettler from GeoForschungsZentrum in Potsdam and Witold Szczucinski from Adam Mickiewicz University in Poznan for providing their unpublished data. We also would like to thank Marta Głuchowska for help with statistical analyses and Jan Marcin Weslawski for comments on an earlier version of the manuscript. Additionally, Dieter Piepenburg, Aleksander Drgas, and two anonymous reviewers are acknowledged for constructive comments leading to an improved manuscript. This study was completed thanks to financial support from the Polish Ministry of Science and Higher Education (ATBI project- 333/N-IPY/2008).

Open Access This article is distributed under the terms of the Creative Commons Attribution Noncommercial License which permits any noncommercial use, distribution, and reproduction in any medium, provided the original author(s) and source are credited.

\section{References}

Ambrose WG, Renaud PE (1995) Benthic response to water column productivity patterns: evidence for benthic-pelagic coupling in the Northeast water polynya. J Geophys Res 100:4411-4421

Bell SS, Coull BC (1978) Field evidence that shrimp predation regulates meiofauna. Oecologia 35:141-148

Beszczynska-Moller A, Weslawski JM, Walczowski W, Zajaczkowski M (1997) Estimation of glacial meltwater discharge into Svalbard coastal waters. Oceanologia 39:289-298

Burgess R (2001) An improved protocol for separating meiofauna from sediments using colloidal silica sols. Mar Ecol Prog Ser 214:161-165

Clarke KR, Gorley RN (2006) Primer v.6: user manual tutorial. Primer-E Ltd, Plymouth

Coull BC (1970) Shallow water meiobenthos of the Bermuda platform. Oecologia 4:325-357

Danovaro R, Dinet A, Duineveld G, Tselepides A (1999) Benthic response to particulate fluxes in different trophic environments: a comparison between the Gulf of Lions-Cataln Sea (W-Mediterranean) and the Cretan Sea (E-Mediterranean). Prog Oceanogr 44:287-312
Eilertsen HC, Taasen JP, Weslawski JM (1989) Phytoplankton studies in the fjords of West Spitzbergen: physical environment and production in spring and summer. J Plankton Res 11:1245-1260

Falkowski PG, Fenchel TM, Delong EF (2008) The microbial engines that drive Earth's biogeochemical cycles. Science 320:1034-1039

Fenchel TM, Jørgensen BB (1977) Detritus food chains of aquatic ecosystems: the role of bacteria. Adv Microb Ecol 1:1-58

Giere O (2009) Meiobenthology. The microscopic motile fauna of aquatic sediments, 2nd edn. Spirnger, Beriln

Görlich KA, Weslawski JM, Zajaczkowski M (1987) Suspension settling effect on macrobenthos biomass distribution in the Hornsund fjord, Spitsbergen. Polar Res 5:175-192

Graf G (1989) Benthic-pelagic coupling in deep-sea benthic community. Nature 341:437-439

Grebmeier JM, Barry JP (1991) The influence of oceanographic processes on pelagic-benthic coupling in polar regions: a benthic perspective. J Mar Syst 2:495-518

Holte B, Dahle S, Gulliksen B, Naes K (1996) Some macrofaunal effects of local pollution and glacier induced sedimentation, with indicative chemical analyses, in the sediments of two Arctic fjords. Polar Biol 16:549-557

Hop H, Pearson T, Hegseth EN, Kovacs KM, Wiencke C, Kwasniewski S, Eiane K, Mehlum F, Gulliksen B, Wlodarska-Kowalczuk M, Lydersen C, Weslawska JM, Cochrane S, Gabrielsen GW, Leakey RJG, Lønne OJ, Zajaczkowski M, Falk-Petersen S, Kendall M, Wängberg SA, Bischof K, Voronkov AY, Kovaltchouk M, Wiktor J, Poltermann M, Di Prisco G, Papucci C, Gerland S (2002) The marine ecosystem of Kongsfjorden, Svalbard. Polar Res 21:167-208

Hulings NC, Gray JS (1976) Physical factors controlling abundance of meiofauna on tidal and atidal beaches. Mar Biol 34:77-83

Jania J (1988) Dynamiczne procesy glacjalne na Południowym Spitsbergenie (w świetle badań fotointerpretacyjnych i fotogramatyczne). Prace Naukowe Uniwersytetu Śląskiego w Katowicach nr 955, in polish

Jankowska K, Wlodarska-Kowalczuk M, Wieczorek P (2005) Abundance and biomass of bacteria in two Arctic glacial fjords. Pol Polar Res 26:77-84

Jiang X, He J, Cai M (2005) Abundance and biomass of heterotrophic microbes in the Kongsfjorden, Svalbard. Acta Oceanol Sinica 24:143-152

Keck A, Wiktor J, Hapter R, Nilsen R (1999) Phytoplankton assemblages related to physical gradients in an arctic glacier-fed fjord in summer. ICES J Mar Sci 56:203-214

Kedra M, Wlodarska-Kowalczuk M (2008) Distribution and diversity of sipunculan fauna in high Arctic fjords (west Svalbard). Polar Biol 31:1181-1190

Kendall MA (1994) Polychaete assemblages along a depth gradient in a Spitsbergen fjord. In: Dauvin JC, Laubier L, Reish DJ (eds) Actes de la 4éme Conference internationale des polychétes. Mem Mus nat Hist Nat paris Serc 162:463-470

Kendall MA, Aschan M (1993) Latitudinal gradients in the structure of macrobenthic communities: a comparison of Arctic, temperate and tropical sites. J Exp Mar Biol Ecol 172:157-169

Kennedy A, Jacoby CA (1999) Biological indicators of marine environmental health: meiofauna- a neglected benthic component? Environ Monit Assess 54:47-68

Kotwicki L, Szymelfenig M, De Troch M, Zajaczkowski M (2004) Distribution of meiofauna in Kongsfjorden, Spitsbergen. Polar Biol 27:661-669

Lee HJ, Gerdes D, Vanhove S, Vincx M (2001a) Meiofauna response to iceberg disturbance on the Antarctic continental shelf at Kapp Norvegia (Weddell Sea). Polar Biol 24:926-933

Lee HJ, Vanhove S, Pech LS, Vincx M (2001b) Recolonisation of meiofauna after catastrophic iceberg scouring in shallow Antarctic sediments. Polar Biol 24:918-925 
Lefauconnier B, Hagen JO, Rudant JP (1994) Flow speed and calving rate of Kongsbreen glacier, Svalbard, using SPOT images. Polar Res 13:59-65

Legezynska J, Weslawski JM, Presler P (2000) Benthic scavengers collected by baited traps in the high Arctic. Polar Biol 23:539-544

Maciejewska B (2007) Biodiversity of the arctic macrobenthos in Hornsund fjord (Svalbard). Diploma Thesis (in polish), University of Gdansk, Poland

McLachlan A (1977) Composition, distribution, abundance and biomass of macrofauna and meiofauna of four sandy beaches. Zool Afr 12:257-277

McLachlan A, Brown AC (2006) The ecology of sandy shores, 2nd edn. Academic Press, USA, p 373

Montagna PA, Coull BC, Herring TL, Dudley BW (1983) The relationship between abundances of meiofauna and their suspected microbial food (diatoms and bacteria). Estuar Coast Shelf Sci 17:381-394

Moreno M, Ferrero TJ, Granelli V, Marin V, Albertelli G, Fabiano M (2006) Across shore variability and trophodynamic features of meiofauna in microtidal beach of the NW Mediterranean. Estuar Coast Shelf Sci 66:357-367

Okolodkov YB, Hapter R, Semovski SV (2000) Phytoplankton in Kongsfjorden. Sarsia 85:345-352

Palli A, Moore JC, Jania J, Glowacki P (2003) Glacier changes in southern Spitsbergen, Svalbard, 1901-2000. Ann Glaciol 37:219-225

Piquet AM-T, Scheepens JF, Bolhuis H, Wiencke C, Buma AGJ (2010) Variability of protistan and bacterial communities in two Arctic fjords (Spitsbergen). Polar Biol 33:1521-1536

Piwosz K, Walkusz W, Hapter R, Wieczorek P, Hop H, Wiktor J (2009) Comparison of productivity and phytoplankton in a warm (Kongsfjorden) and a cold (Hornsund) Spitsbergen fjord in midsummer 2002. Polar Biol 32:549-559

Robador A, Brüchert V, Jorgensen BB (2009) The impact of temperature change on the activity and community composition of sulfate-reducing bacteria in arctic versus temperate marine sediments. Environ Microbiol 11:1692-1703

Ronowicz M (2005) Species diversity of Arctic gravel beach: case study for species poor habitats. Pol Polar Res 26:287-297

Ronowicz M, Wlodarska-Kowalczuk M, Kuklinski P (2008) Factors influencing hydroids (Cnidaria:Hydrozoa) biodiversity and distribution in Arctic kelp forest. J Mar Biol Assoc UK $88: 1567-1575$

Saloranta TM, Haugan PM (2004) Northward cooling and freshening of the warm core of the West Spitsbergen current. Polar Res 23:79-88

Schratzberger M, Warwick RM (1998) Effects of physical disturbance on nematode communities in sand and mud: a microcosm experiment. Mar Biol 130:643-650

Serreze MC, Walsh JE, Chapin FS III, Osterkamp T, Dyurgerov M, Romanovsky V, Oechel WC, Morison J, Zhang T, Barry RG (2000) Observational evidence of recent change in the northern high-latitude environment. Clim Change 46:159-207

Somerfield PJ, Clarke KR (1997) A comparison of some methods commonly used for the collection of sublittoral sediments and their associated fauna. Mar Environ Res 43:145-156

Steyaert M, Moodley L, Nadong T, Moens T, Soetaert K, Vincx M (2007) Responses of intertidal nematodes to short-term anoxic events. J Exp Mar Biol Ecol 345:175-184

Svendsen H, Beszczynska-Möller A, Hagen JO, lefauconnier B, Tverberg V, Gerland S, Ørbæk JB, Bischof K, Papucci C, Zajaczkowski M, Azzolini R, Bruland O, Winther J-G, Dallmann W (2002) The physical environment of Kongsfjorden-Krossfjorden, an Arctic fjord system in Svalbard. Polar Res 21:133-166
Swerpel S (1985) The Hornsund fjord:water masses. Pol Polar Res 6:475-496

Szczucinski W, Scholten J, Zajaczkowski M (2006) Impact of glaciers retreat on sediment accumulation rates in fjords-changes following "little ice age" in Billefjorden, Svalbard. In: Fourth ESF SEDIFLUX science meeting \& first workshop of I.A.G./A.I.G SEDIBUD: source to sink fluxes and sediment budgets in cold environments. NGF abstracts and proceedings of the geological society of Norway 4:66

ter Braak CJF, Smilauer P (2002) CANOCO reference manual and canocodraw for windows user's guide: software for canonical community ordination (Version 4.5). Microcomputer Power, Ithaca

Throndsen J (1970) Flagellates from Arctic waters. Nor J Bot 17:49-57

Urban-Malinga B, Drgas A, Ameryk A, Tatarek A (2009) Meiofaunal (re)colonization of the Arctic intertidal (Hornsund, Spitsbergen) after ice melting role of wrack deposition. Polar Biol 32:243-252

Urbanski J, Neugebauer E, Spacjer R, Falkowska L (1980) Physicochemical characteristics of the waters of Hornsund gjord on south-west Spitsbergen (Svalbard Archipelago) in the summer season 1979. Pol Polar Res 1:43-52

Walczowski W, Piechura J (2006) New evidence of warming propagating toward the Arctic Ocean. Geophys Res Lett 33 doi:10.1029/2006GL025872

Walczowski W, Piechura J (2007) Pathways of the greenland sea warming. Geophys Res Lett 34 doi:10.1029/2007GL029974

Walkusz W (2006) Temporal and spatial variability of zooplankton from two Svalbard fjords: Kongsfjorden and Hornsund. PhD Thesis, Institute of Oceanology, Polish Academy of Science, Sopot, Poland

Warwick RM, Emblow C, Feral JP, Hummel H, Van Avesaath P, Heip C (2003) European marine biodiversity research sites. Report of the European Concerted Action: BIOMARE. NIOO-CEME, Yerseke, The Netherlands, p 136

Wentworth CK (1922) A scale of grade and class terms for clastic sediments. J Geol 30:655-744

Weslawski JM, Legezynska J (1998) Glaciers caused zooplankton mortality? J Plankton Res 20:1233-1240

Weslawski JM, Jankowski A, Kwasniewski S, Swerpel S, Ryg M (1991) Summer hydrology and zooplankton in two Svalbard fiords. Pol Polar Res 12:445-460

Weslawski JM, Kwasniewski S, Stempniewicz L, Blachowiak-Samolyk K (2006) Biodiversity and energy transfer to top trophic levels in two contrasting Arctic fjords. Pol Polar Res 27:259-278

Weston NB, Joye SB (2005) Temperature-driven decoupling of key phases of organic matter degradation in marine sediments. Proc Natl Acad Sci U S A 102:17036-17040

Wetzel MA, Weber A, Giere O (2002) Re-colonization of anoxic/sulfidic sediments by marine nematodes after experimental removal of macroalgal cover. Mar Biol 141:679-689

Wiktor J, Wojciechowska K (2005) Differences in taxonomic composition of summer phytoplankton in two fjords of West Spitsbergen, Svalbard. Pol Polar Res 26:259-268

Wlodarska-Kowalczuk M (2001) Macrozoobenthos in the disturbed environment of the glacial bay (Kongsfjorden, Spitsbergen). $\mathrm{PhD}$ Thesis (in polish), University of Gdansk

Wlodarska-Kowalczuk M, Pearson TH (2004) Soft-bottom macrobenthic faunal associations and factors affecting species distributions in an Arctic glacial fjord (Kongsfjorden, Spitsbergen). Polar Biol 27:155-167

Wlodarska-Kowalczuk M, Pearson TH, Kendall MA (2005) Benthic response to chronic natural physical distrubance by glacial sedimentation in an Arctic fjord. Mar Ecol Prog Ser 303:31-41

Wlodarska-Kowalczuk M, Kuklinski P, Ronowicz M, Legezynska J, Gromisz S (2009) Assessing species richness of macrofauna 
associated with macroalgae in Arctic kelp forests (Hornsund, Svalbard). Polar Biol 32:897-905

Zajaczkowski M (2008) Sediment supply and fluxes in glacial and outwash fjords, Kongsfjorden and Adventfjorden, Svalbard. Pol Polar Res 29:59-72
Zeng Y, Zheng T, Li H (2009) Community composition of the marine bacterioplankton in Kongsfjorden (Spitsbergen) as revealed by 16S rRNA gene analysis. Polar Biol 32:1447-1460 